\title{
KNOWLEDGE TRANSFER IN THE ORGANIC FARMING SYSTEM: THE ROLE OF AGRICULTURAL ADVISORY SERVICES
}

\author{
Ruta Śpiewak $^{1 \otimes}$, Jakub Jasiński ${ }^{1}$ \\ ${ }^{1}$ Polish Academy of Sciences, Institute of Rural and Agricultural Development, Poland
}

\begin{abstract}
In Poland, organic farming has been growing steadily though less rapidly than in other EU Member States. As organic farming is based on knowledge and innovation, access to various kinds of information is critical for its development. Having the above in mind, the authors undertook to investigate the system of knowledge transfer in organic farming and to analyze the impact it has on the development of the organic food market. This paper presents a qualitative study on organic farmers, agricultural advisors and researchers with interest in organic farming (conducted in 2017). It focuses on the role of Agricultural Advisory Centers in knowledge transfer in the organic farming sector because agricultural advisory services are central to the entire knowledge transfer system (while not playing a major role). Research results show that both farmers and advisors claim there are many shortcomings in the knowledge transfer system, caused by multiple factors, including the underfunding of agricultural advisory services, absence of advisors specializing solely in organic farming, and inefficient management of advisory institutions. The increasing significance of private centers was also highlighted. The weakness of the advisory services system could be one of the reasons why organic farming in Poland does not develop as rapidly as in other EU countries.
\end{abstract}

Keywords: organic farming, knowledge, Agricultural Advisory Center, farming in Poland

\section{INTRODUCTION}

In the European Union, consumer awareness of organic foodstuffs has been increasing incessantly, and so has the number of organic farms and crop volume. Between 1999 and 2015, the retail sales volume of organic food increased almost fivefold in Europe. The most recent report by the Supreme Audit Office (NIK) says that the average European Union citizen spends EUR 44 on organic products, a Danish citizen spends EUR 200 while a Pole spends EUR 11 (https://www.nik.gov.pl/).

After a period of dynamic development of organic farming in Poland between 2004 and 2013, the next two years (2014-2015) witnessed an opposite trend characterized by a decrease in the number of system participants (Luczka, 2018). It was mainly attributed to a sudden drop in the number of organic farms in Poland and, even more so, to a decline in the area of organic farmland (Drygas, 2017; Jasiński, 2016; Tyburski, 2017). A slow increase in these figures has only been visible since 2016 (Agricultural and Food Quality Inspection (Raport o..., 2016)).

Apart from its primary purpose, which is to produce high-quality food from natural ingredients while respecting natural lifecycles, organic farming also has other functions (Framework Action Plan..., 2018), including, without limitation:

- to increase agricultural income,

- to increase and diversify rural employment,

- to care for the environment and landscape,

- to develop food supply chains, especially local ones (Jasiński et al., 2014b).

\footnotetext{
$\bowtie$ Ruta Śpiewak, PhD, Polish Academy of Sciences, Institute of Rural and Agricultural Development, Nowy Świat 72 St., 00-330 Warsaw, Poland, e-mail: ruta.spiewak@irwirpan.waw.pl, https://orcid.org/0000-0001-8336-8414
} 
The abovementioned functions can be fulfilled by the organic farming sector if it develops incessantly and if organic food output increases in the most effective way while respecting the principles of organic production. Organic farming is a sub-sector of agriculture based on knowledge and innovation to a greater extent than other sub-sectors, and one which at the same time contributes to diffusion of technological and social innovation (Jasiński et al., 2014c; Marsch, 2016; Padel, 2001).

The development of commercial organic farming is only possible through increasingly innovative - yet invariably organic - methods and means of crop cultivation and animal husbandry, and through a close cooperation between organic farmers and processors, one the one side, and researchers and advocates of state-of-theart solutions (advisors) one the other.

The role of Agricultural Advisory Centers in the knowledge transfer process can be compared to that of a conveyor belt: not only do they convey information to farmers, but also they continuously gather feedback, and report the farmers' and producers' demand for specific knowledge and solutions to the academic community and decision-makers (Staniszewski, 2014). Sokołowska describes agricultural advisory services as "a unique informal method of lifelong learning for farmers and rural residents. Thanks to the use of rational communication tools, it may trigger voluntary behavior which enables targeting the processes that take place in agricultural holdings" (Sokołowska, 2014, p. 123).

The investigation into the role of the knowledge transfer system in the development of organic farming is a new concept in Poland. In this context, the purpose of knowledge transfer is not only to enhance the income of individual farmers, but also to generate value added in rural areas, including through: a commitment to the highest possible benefits (profits) for rural areas; the development of local communities; enhanced activity of the rural population; efforts taken to make rural areas a more attractive place; and the use of state-of-the-art (but at the same time natural) methods for crop cultivation and animal husbandry (cf. Jasiński, 2016; Jasiński et al., 2014b; 2014c). Even in countries where organic farming is backed up by a stronger tradition and highly experienced organic farmer organizations, the subject has not been described in depth; the relevant literature is rather poor and requires a theoretical background to enable the creation of nomenclature and the establishment of an analytic framework (cf. Knickel et al., 2008; Dumont and Baret, 2017).

Hence, our research team undertook to fill in the gap while continuing the research into the condition of organic farming in Poland, which started in 2013. (Jasiński, 2014c). Between May and November 2017, a study on The Knowledge Transfer System in Organic Farming - Determination of Barriers to Market Development ${ }^{1}$ was carried out thanks to financial assistance from the Ministry of Agriculture. The purpose of the study was to analyze the functioning of the knowledge transfer system in organic farming to determine the extent to which it can become a barrier to or a driver of organic food market development. This paper focuses on one selected aspect of the study, namely the analysis of the role and function of Agricultural Advisory Centers (AACs) in the development of organic farming and processing. The authors wanted to see if the advisors and researchers are supporting the growth of organic market-oriented farming.

An assumption was made that AACs do not sufficiently support the development of organic farming. This indirectly results from the fact that the role and importance of organic production is underestimated by Polish decision-makers. The direct reasons are the lack of specialists among AAC employees and the ineffective cooperation between advisors and researchers.

\section{PURPOSE, METHODOLOGY AND RESEARCH TOOLS}

An assumption was made that the knowledge transfer chain (system) comprises three major links:

- organic producers (farmers and processors) and their needs,

- agricultural advisors together with the institutional base,

- scientific units that possess knowledge and are open to real market needs.

In addition to determining the demand of organic food producers for knowledge on various aspects of

\footnotetext{
${ }^{1}$ Andrzej Hałasiewicz and Małgorzata Gelo also participated in this research project. The project was awarded a grant from the Ministry of Agriculture and Rural Development to cover the costs of research in organic farming incurred in 2017.
} 
organic production systems, an analysis was carried out of how research centers (which can investigate into the methods and principles of crop cultivation and animal husbandry) respond to the demand of organic farmers for knowledge and innovation. Furthermore, it was important to examine the operation of the agricultural advisory services system in the area of organic production, including cooperation between advisors and the academic community.

This paper focuses on the latter aspect because, as already mentioned above, agricultural advisory services are central to the entire knowledge transfer system (while not playing a major role). Hence, the primary purpose of this paper is to analyze the extent to which AACs can be perceived as a barrier to or a driver of development of organic farming and of the organic food market.

No research in this field was carried out in Poland, and hence no specific hypotheses can be formulated based on previous findings. Therefore, the authors considered it best to resort to qualitative studies which, as the most suitable tool in these circumstances, depict the situation of Polish organic producer organizations, organic farming-oriented Agricultural Advisory Centers, universities and research institutes involved in developing the organic sector. When opening a new field of study, it is reasonable to start with an in-depth analysis of a smaller number of cases instead of roughly analyzing a large sample without raising important questions that require in-depth methods (Silverman, 2018).

\section{SAMPLING}

In the case of a study like this one, it is best to use a purposive sample. As the selection criteria for a purposive sample are ambiguous (Flick, 2009), the likelihood of a unit finding its way to the sample cannot be determined. An expert panel, composed of five experts who deal with (and research into) the organic food market and organic farming development, indicated the following locations:

1) operation venues of organic producer organizations, associations, and groups

2) Agricultural Advisory Centers

3) institutes/universities who participate in the knowledge transfer system in the organic farming sector (i.e. who conduct research into organic farming or organic food production) $)^{2}$.

Based on indications of the expert panel, the research team selected eight locations of dynamic, organized groups of organic farmers or agricultural producers and processors (not necessarily being members of a producer group). In each location, one in-depth interview (IDI) was conducted with the leader of the organic farmer or processor organization. Also, one focused group interview (FGI) was carried out with organization members. In each voivodeship where the organizations considered are active, one or two individual interviews were conducted with the AAC personnel who worked with the representatives of the organic farming organizations under analysis. In the course of the study, it turned out that in some places, private consultancy entities also play an important role in the knowledge transfer system. Therefore, though not initially planned $^{3}$, two additional interviews with representatives of private advisory companies were conducted (see Fig 1). Interviews in Agricultural Advisory Centers from the selected locations were preceded by two individual interviews (IDIs) with the management of the Agricultural Advisory Center in Brwinów (Branch Office in Radom) which is Poland's main training center for organic farming advisors. The third element of the study consisted in analyzing the scientific work and the operation of research centers focused on organic farming. The team interviewed eight researchers from five research centers located in various parts of Poland who conduct research into organic farming or organic food production.

Map of locations covered by the research:

\footnotetext{
${ }^{2}$ According to the assumptions, this study included analyzing how agricultural advisory services work in the knowledge transfer system, as per the following model:

a) institutional cooperation (with farmers, processors, AACs, research units),

b) knowledge transfer (dissemination): effectiveness, needs and realities,

c) the strongest and the weakest links in the knowledge transfer process (with reference to the agricultural advisory services system).

${ }^{3}$ The organizations of organic farmers or organic producers and processors covered by the study were located in: Mazowieckie voivodeship (1 location), Podlaskie voivodeship (1 location), Lubelskie voivodeship (2 locations), Kujawsko-Pomorskie voivodeship (1 location) and Zachodniopomorskie voivodeship (2 locations). The study also covered the representatives of one national organization.
} 


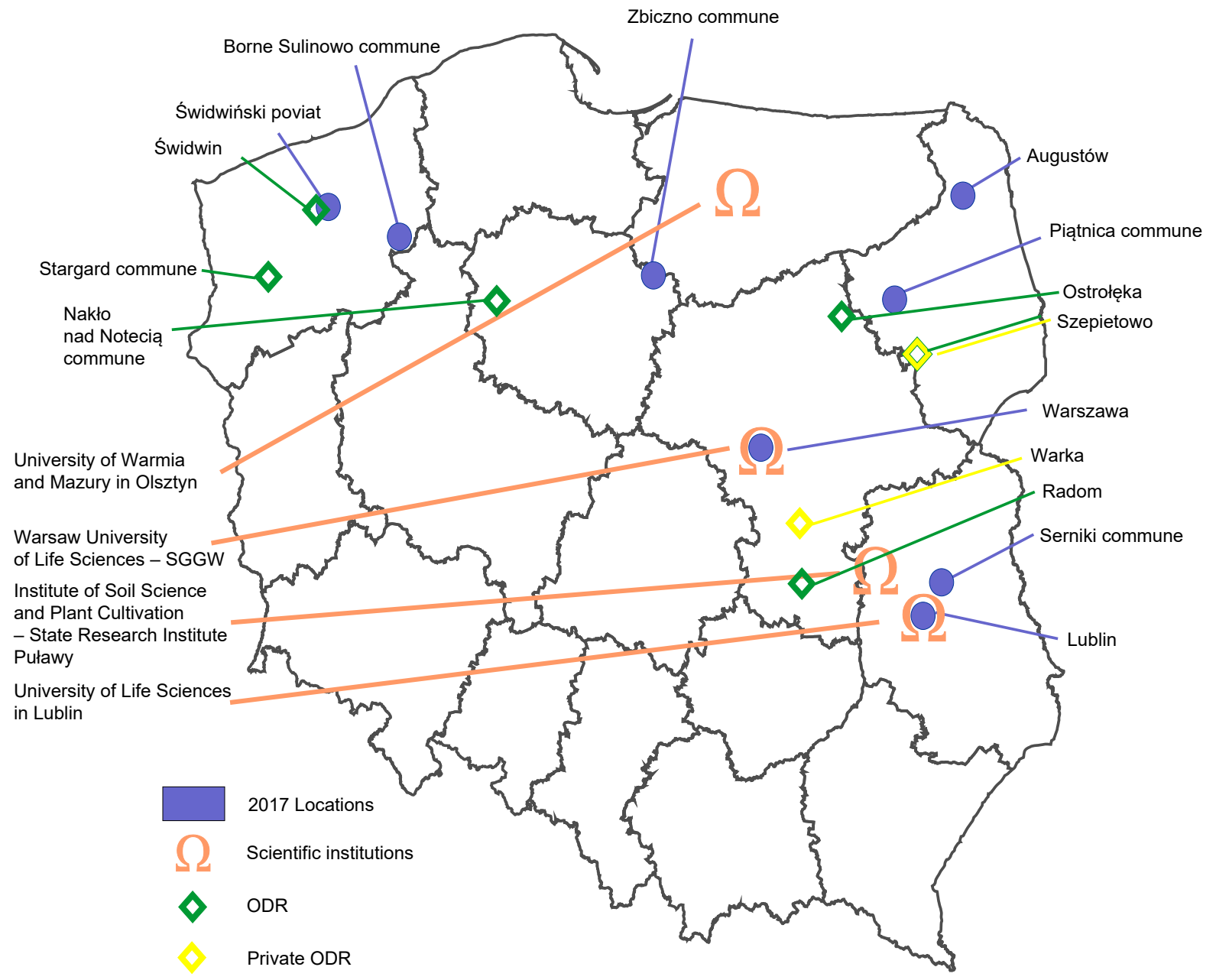

Fig. 1. Map of Poland with marked interviewed locations Source: own elaboration.

\section{RESULTS}

All the organic farmers and producers who participated in the study emphasized the key importance of professional agricultural advisory services for the development of organic farming. On the one hand, demand exists for the advisors' agronomic knowledge and for services that would go beyond teaching how to devise agri-environmental plans and fill in applications for payments. On the other hand, it seems essential for the advisors to work onsite to a greater extent. According to the respondents, at present: "Enormous amounts of money are spent on organic farming, but there is no

system in place that would ensure the funds are spent in an optimal way; the consultancy system is not effective because advisors are not doing what they could do or are supposed to do" [FGI]. In the view of the respondents, decision makers do not realize the importance or multifaceted role of agriculture, or the role to be played by agricultural advisory services: "They do not understand their [AACs'] role, functions, or how much we need them. Agriculture stands not only for crops, but also for environmental protection. Farmland covers $60 \%$ of Poland, if you do it the wrong way - because most pollutants come from agriculture..." [IDI]. 
The problem is that advisors lack sufficient knowledge of organic production and processing methods. Instead, they focus on formal issues connected with the optimization of funding obtained by the farmers. This situation can be attributed to a number of factors. Agricultural advisors have no relevant expertise in organic farming and production systems which tend to change on an ongoing basis. As they claim themselves, they spend most of their time filling in applications for payments and drafting agri-environmental plans. This is the result of an increasing number of documents that must be prepared by organic farmers, who hence seek assistance from the advisors. The advisors, in turn, lack time and funds to expand and update their knowledge of agronomy. The organization of work in Agricultural Advisory Centers places focus on providing support to farmers in formal issues as these generate much needed revenue for the Centers. The personnel are not motivated to seek out new information. "I think that the problem lies in the system of the Centers' operation, and in what they are focused on in their work. Indeed, assistance in agronomy issues has been neglected by Agricultural Advisory Centers" [FGI].

Due to very limited funds, including for traveling to meet farmers, advisors spend little time in individual holdings. Hence, farmers are even more inclined to believe that the advisors focus solely on formal issues rather than on specific problems of practical importance. "Advisors must visit a farm, they must see a farm for themselves. They must treat a farm as a single organism. Only then, with good insight, can [advisory services] be effective and meet the farmers' expectations" [IDI].

In Poland, as advisors are not familiar with the subject of organic farming, this sector excessively relies on traditions, traditional varieties, traditional crops, etc. Yet, it is just as plausible to use innovative tools, techniques and methods in organic production, the only condition being the legal requirements for organic production. "In my opinion, innovation is one of the weaknesses of organic farming in Poland. Farming puts on a pretence of tradition rather than innovation as if innovation and organic farming did not match. Yet I believe that we can and we need to pursue organic farming in modern ways" [IDI]. Such measures would perhaps result in an increased scale of organic output, but it would require intensive development of research and a close cooperation between producers, processors, and universities that should assist Agricultural Advisory Centers.
The relations between research centers and advisory centers are irregular, and no effective communication channels have been worked out so far. Researchers are not always familiar with the needs of farmers, while advisors usually claim they look for information online instead of contacting researchers due to lack of time, no motivation from their management, and lower costs. Farmers and advisors alike also complained that some researchers and their research remain detached from real life, everyday practice, real needs and experience. "[In my opinion] they only occasionally work with farmers and practitioners. And when a Ph.D. holder comes who specializes in a given field but only on paper (it is frequently the case) ... and, God forbid, when there are farmers with us at these trainings ... the atmosphere in the lobby can get really hot sometimes" [IDI]. The advisors also complain that useful papers are rarely passed on to AACs, and even when they are, they are written in a language that is difficult to understand or sometimes altogether incomprehensible.

Prior research (Jasiński, 2016; Jasiński et al., 2014b) shows that commercial organic farming develops better when farmers are organized into formal groups (for instance producer groups or associations). This result both from economic factors (lower transaction costs and social costs) and from a closer integration of this social group. It is extremely rare for Agricultural Advisory Centers to address issues relating to the establishment of farmer organizations and marketing efforts.

Although private advisory services are not highly regarded by farmers, commercial advisors contacted by the research team have fulfilled the functions which state-owned centers were unable to fulfill. Commercial advisors covered by this analysis are familiar with the holdings they work with; if they do not have adequate knowledge of technology, they know just where and how to find it. In the opinion of the respondents, there should be healthy competition between state-owned and private advisory companies. Nonetheless, stateowned advisory centers must remain on the market because many small farmers simply cannot afford to pay for private services. As one of the interviewed farmers claimed: "On the one hand, they compete with each other, but on the other hand competition stimulates healthy development. I also think there is room for both types of organizations on the market. Some of the paperwork in the state-run system is commercial just as in the case of private advisors" [IDI] 
Compared to conventional production, organic production requires higher competences from producers both at production and marketing stage - in order to become profitable. As shown by this research, farmers do not obtain required knowledge from the dedicated institutions. This is because most advisors do not have the relevant knowledge and are not motivated to deepen their marketing and organic farming skills. Both the farmers themselves and the AACs fail to duly recognize the issue of formal organization of farmers, which is of great importance for the development of the organic farming sector. Also, the channels of cooperation with scientific employees have not been developed.

\section{CONCLUSIONS}

This study covered the locations where commercial organic farms have been operating for long periods of time, and hence the sector is quite sound and resilient. In most of these locations, even if dedicated organic farming departments were in place in district-level Agricultural Advisory Centers, they failed to meet the expectations of organic producers when it comes to support for production or processing technologies. What is more, even the advisors themselves admitted that although organic farming is an important line of development of agriculture, they had no tools or time to focus on supporting such holdings.

It can be assumed that the AACs do not fully explore the opportunities created by the Rural Development Program as part of two measures under priority axis I: 1 . vocational training for persons employed in agriculture; and 2. use of advisory services, as well as other activities related to development of innovation and cooperation.

There are several factors behind the slow increase in the number of organic producers in recent years in Poland. Certainly, one of those factors is insufficient support from the institutions which, at least theoretically or formally, are dedicated to serve that purpose. Being an ineffective conveyor belt between farmers and researchers, Agricultural Advisory Centers fail to support innovation development in organic farming.

In order for AACs to be more efficient in supporting the growth of the market sector of organic farming, it is crucial to establish a team of advisors dedicated only to organic farming, especially in regions where it is thriving. Undoubtedly, the earnings of advisors should be raised. At the same time, a motivation system should be put in place to constantly improve their competences. It is also important to create an incentive system for researchers to engage in applicative research. Furthermore, cooperation needs to established with mass media so that both consumers and producers become more interested in organic production.

In summation, AACs in their present form do not stimulate the development of commercial organic farming. Moreover, with a rapid increase in consumption of organic food globally, it can be assumed that the absence of support in the area of state-of-the-art organic production methods results in a situation where the system of agricultural advisory services constitutes an obstacle to the development of a sound organic farming sector.

\section{REFERENCES}

Drygas M., Bańkowska K., Nurzyńska I., Wyceh K, (2017). Uwarunkowania ekonomiczne i społęczne rozwoju rolnictwa ekologicznego w Polsce (raport z badań). [Economic and social determinants of the development of organic farming in Poland (research report).] Retrieved June 13, 2018 from: http://www.irwirpan.waw.pl/polski/ Raport_Uwarunkowania_ekonomiczne_i_spoleczne_rozwoju-2007.pdf [in Polish].

Dumont A.M., Baret P.V. (2017). Why working conditions are a key issue of sustainability in agriculture? A comparison between agroecological, organic and conventional vegetable systems. Journal of Rural Studies, 56, 53-64. DOI: 10.1016/j.jrurstud.2017.07.007

Flick U. (2009). An introduction to qualitative research. Wyd. 4. London: Sage Publications.

Flyvbjerg B. (2005). Pięć mitów o badaniach typu studium przypadku.[Five myths about case study cases], Studia Socjologiczne, 177 (2).[in Polish].

Jasiński J. (2016). Jakość rządzenia na poziomie lokalnym a efektywność wykorzystania endogenicznych potencjałów wsi. Niepublikowana praca doktorska, [The quality of governance at the local level and the role of using the endogenous potentials of the rural areas]. Unpublished doctoral thesisIRWiR PAN. Warszawa. [in Polish].

Jasiński J., Michalska S., Śpiewak R. (2014a). Rolnictwo ekologiczne jako czynnik rozwoju lokalnego. [Organic farming as a factor of local change]. Wieś i Rolnictwo, 4 (165), 145-158. [in Polish].

Jasiński J., Michalska S., Śpiewak R. (2014b). Rynki zakorzenione - koncepcja uruchomienia mechanizmów lokalnego rozwoju. [Nested market - a new mechanism for local development], Wieś i Rolnictwo, 3 (164), 105-123. [in Polish]. 
Śpiewak, R., Jasiński, J. (2019). Knowledge transfer in the organic farming system: the role of agricultural advisory services. J. Agribus. Rural Dev., 1(51), 77-83. http://dx.doi.org/10.17306/J.JARD.2019.01111

Jasiński J., Michalska S., Śpiewak R. (2014c). Rolnictwo ekologiczne czynnikiem rozwoju lokalnego - analiza wybranych przypadków. [Organic farming as a factor of local change - analysis of selected cases] W: Wyniki badań z zakresu rolnictwa ekologicznego realizowanych w 2013 roku (s. 434-447). Warszawa: Ministerstwo Rolnictwa i Rozwoju Wsi. [in Polish].

Jasiński J., Śpiewak R. Hałsiewicz A., Gelo-Kluczyńska M. (2017). System transferu wiedzy w rolnictwie ekologicznym. Określenie barier rozwoju rynku. [Knowledge transfer system in organic farming. Identification of barriers] Retrieved May 11, 2018 from: (http://admin.www.irwirpan.waw.pl/dir_upload/site/files/Raport_IRWiR_2017_final.pdf [in Polish]

Knickel K., Brunori G., Rand S., Proost J. (2008). Towards a better conceptual framework for innovation processes in agriculture and rural development: from linearmodels to systemic approaches. $8^{\text {th }}$ European IFSA Symposium.

Łuczka W. (2018). The changes on the Organic Food Market, Journal of Agribusiness and Rural Development 4 (42).

Marsch L. (2016). Organic farming: knowledge, practices, and views of limited resource farmers and non-farmers on the Delmarva Peninsula. Organic Agriculture June 2017, Volume 7, Issue 2 doi.org/10.1007/s13165-016-0150-x

https://www.nik.gov.pl/aktualnosci/rolnictwo-ekologiczneniewykorzystywana-szansa-polski-panel-ekspertow.html (press note). Retrieved June 4, 2018.

Padel S. (2001). Conversion to Organic Farming: A Typical Example of the Diffusionof an Innovation? Sociologia Ruralis, Vol 41, Number 1 doi.org/10.1111/1467-9523.00169

Ramowy Plan Działań dla Żywności i Rolnictwa Ekologicznego w Polsce (2018). Ministerstwo Rolnictwa i Rozwoju
Wsi. Retrieved June 13, 2018 from: https://www.gov. pl/documents/912055/913531/Ramowy_Plan_Dzia\%C5\%82a\%C5\%84_2014-2020_-_05_06_2018.pdf/17e4ac16-4bc0-b600-884b-acf599e9de59 [in Polish]

Raport o stanie rolnictwa ekologicznego w Polsce w latach 2015-2016 (2017). [Condition of organic farming in Poland. The report 2015-2016]. IJHRS Retrieved June 13, 2018 from: http://www.ijhars.gov.pl/pliki/A-pliki-z-glownego-katalogu/ethernet/2017/pazdziernik/BRE/ Raport\%20o\%20stanie\%20rolnictwa\%20ekologicznego\%20w\%20Polsce\%20w\%20latach\%202015-2016.pdf [in Polish].

Silverman D. (2018). Prowadzenie badań jakościowych. [Conducting quality study]. Wydawnictwo Naukowe PWN [in Polish].

Sokołowska S. (2014). Funkcjonowanie systemu doradztwa rolniczego w opinii rolników województwa opolskiego. [the farm advisory system in the opinion of farmers in the Opolskie Voivodeship], Journal of Agribusiness and Rural Development 1 (31) [in Polish].

Staniszewski J (2014). Doradztwo rolnicze, jako element instytucjonalnego otoczenia polskiej wsi. [Agricultural advisory as an element of the institutional environment of the rural areas in Poland, Roczniki Ekonomiczne Kujawsko-pomorskiej szkoły Wyższej w Bydgoszczy 7.

Tyburski J. (2017). Najważniejsze problemy rolnictwa ekologicznego w Polsce i propozycje działań na rzecz rozwoju rolnictwa i żywności ekologicznej. [main issues regarding the development of organic farming and organic food] Prezentacja przedstawio na Radzie ds. Rolnictwa ekologicznego przy Ministrze Rolnictwa i Rozwoju Wsi, 16 stycznia.[in Polish]. 